\title{
ミニギャップ内沸騰系における扁平気泡と伝熱面間の薄液膜形成特性*
}

\author{
張 耀華*1，宇高 義郎 ${ }^{* 2}$
}

\section{Formation Characteristics of Microlayer between Elongated Bubble and Heating Surface in Mini-Gap Boiling System}

\author{
Yaohua ZHANG $^{* 1}$ and Yoshio UTAKA \\ ${ }^{* 1}$ Yokohama National Univ. Graduate School of Mechanical Engineering \\ Tokiwadai79-5, Hodogaya-ku, Yokohama, 240-8501 Japan
}

In this study, experiments were performed to measure the thickness of the liquid film formed between the heating surface and the vapor bubble with the laser extinction method for the gap size of $0.5,0.3$ and $0.15 \mathrm{~mm}$.Water, toluene and HFE7200 were used as test fluids. It was found that the gap size and bubble forefront velocity determined the initial thickness of microlayer no matter of the kind of testing liquid. Vapor bubble generated by boiling in the present mini-gap grows exponentially due to the rapid evaporation of the thin liquid layer, which makes the phenomena highly transient as opposed to the steady situations considered before. Based on the experimental data and scaling arguments a non-dimensional correlation in terms of capillary number and Bond number is proposed.

Key Words : Mini-Gap Boiling, Microlayer Thickness, Acceleration

\section{1. 緒言}

平行な平面伝熱面間の狭险間隙からなるミニギャップ制限流路内の沸騰現象はプール沸騰と同様にバルク液, 蒸気泡および蒸気泡と伝熱面の間に形成される薄液膜等が複雑に影響し合う。しかし，ミニギャップ内の蒸気泡 は，図1に示すように，制限流路によって押しつぶされることにより扁平形状のまま急速に伝熱面上に拡がる.

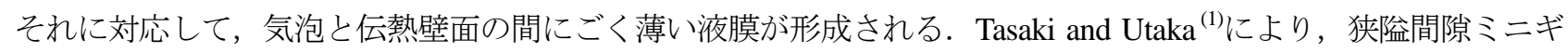

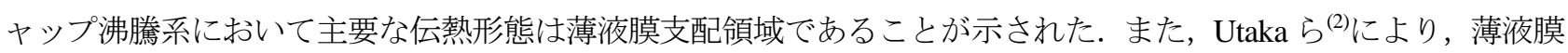
期間と液充満期間の伝熱モデルに基づいて伝熱面過熱度を計算した結果，測定による沸騰曲線と良好な一致が報 告された．他方，狭险間隙の沸騰伝熱機構について，Thome $ら^{(3)}$ は「バルク液体スラグ」,「扁平気泡」及び「蒸 気スラグ」の 3 領域から構成される伝熱モデルを提案した。 そのモデルに基づいて計算した熱伝達率はデータベ 一スからの実験結果と良好な一致を得たが，最も特徵的な「扁平気泡」領域では，予液膜厚さを仮定する必要 がある.したがって，ミニチャネル型蒸発器の性能を予測する上で液膜の形成機構と厚さ予測方法の解明は重要 である.

管内あるいは狭险平行平板間のようなミニチャネル内に形成される液膜の生成機構については，沸騰現象を伴 う場合においても，初期液膜形成に関して，流体力学的な条件に依存するものと考えられるため，断熱二層流に 関する研究結果と併せて検討が可能でと考えられる.気泡の移動速度の低い場合, 速度変化の小さい高速の場合、 および速度が大きく加速のある場合に区分することができる．ミニチャネル内二相流の遅い流れについては,

\footnotetext{
* 原稿受付 2012 年 2 月 28 日

*1 横浜国立大学大学院工学府（干240-8501 神奈川県横浜市保土ヶ谷区常盤台 79-5）

*2 正員, フェロー，横浜国立大学大学院工学研究院（广240-8501 神奈川県横浜市保土ヶ谷区常盤台 79-5)

E-mail: zhang-yaohua-cf@ynu.ac.jp
} 


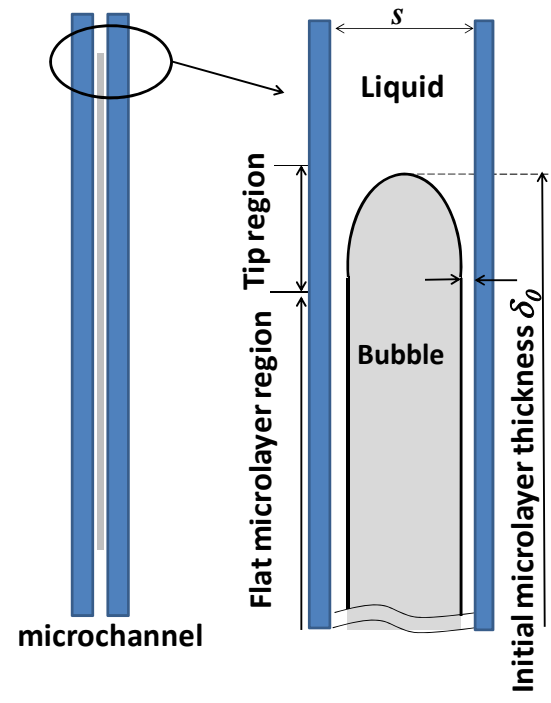

Fig. 1 Schematic diagram of elongated bubble in microchannel

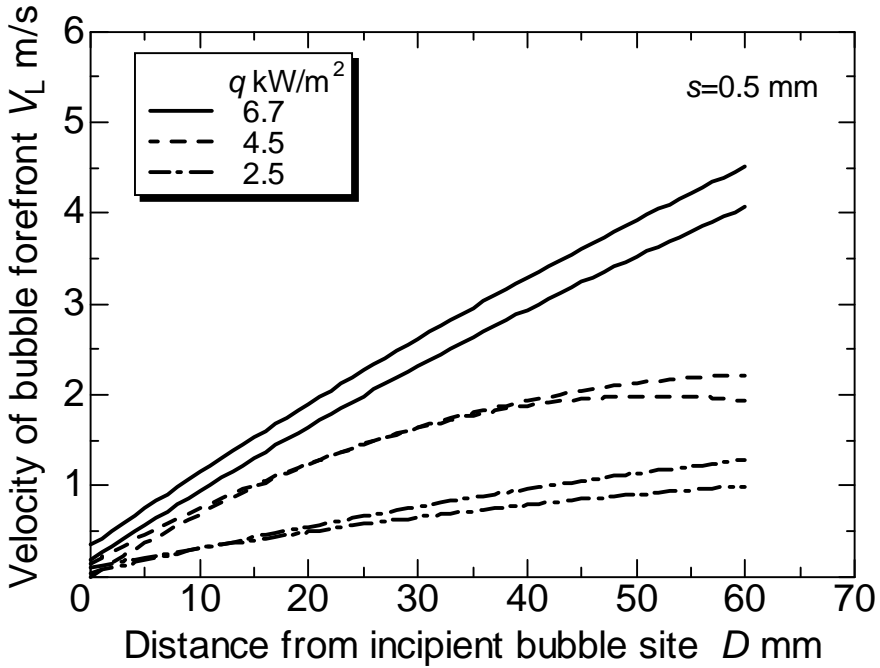

Fig. 2 Velocity of bubble forefront increasing with distance from bubble site by Utaka et al., (2009)

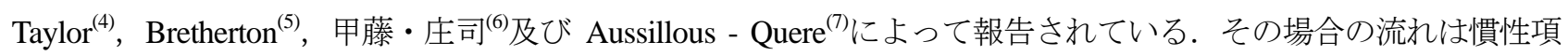
を省略することができ，薄液膜は表面張力に起因する圧力差と液体粘性のついあいにより決められる(8)，そのた め, 無次元薄液膜厚さは粘性力と表面張力の割合を表わ寸 $C a$ 数, $C a=\mu_{L} V_{L} / \sigma$, の関数になることが明らかに されている，さらに，速度変化が小さい比較的高速流れの場合，慣性力の影響を考慮する必要がある. Aussillous $ら^{(7)}$ は定常ナビエ・ストークス方程式のスケーリング分析に基づき，無次元薄液膜厚さを $C a$ 数とWe 数, $W e=\rho s V_{L}^{2} / \sigma$, の関数として関係式を導き出した. 他方, Han - Shikazono ${ }^{(9)}$ は細円管内気液二相流実験デー タより, $\mathrm{Ca}$ 数, We 数と Re 数を併用し, 層流と乱流の場合について, それぞれ整理式を提案した. しかし, ミニ チャネル内沸騰の場合は気液界面の蒸発より, 気泡成長速度は一定でなく, 図 2 に示した Utaka $ら^{(1)}$ の報告に示 されるように，加速されながら成長する．Moriyama - Inoue ${ }^{(10)}$ は，R113 を用いて水平狭险平行平板間における沸 騰実験を行い, 薄液膜の形成機構について Bo 数, $B o=\rho s^{2} a / \sigma ， の$ 值が 2 を境界として, Ca 数支配と粘性境 界層支配の 2 領域に分類し, それらの整理式を提示した. Han - Shikazono ${ }^{(11)}$ は文献 ${ }^{(8)}$ と同じ方法で細管内における 加速二相流の薄液膜厚さを測定し, Bo 数が 1 以上のデータに対し, $C a$ 数と Bo 数の関数として整理式を提案した. また, Han-Shikazono ${ }^{(11)}$ は Moriyama-Inoue ${ }^{(10)}$ の方法で水, エタノールと FC40 の測定結果を整理したが, 物性值の

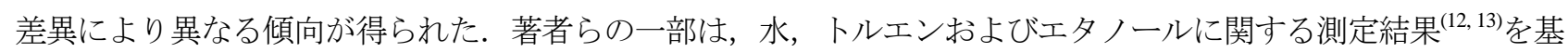
に, Moriyama-Inoue ${ }^{(10)}$ の整理方法に基づいて Ca 数の代わりにWe 数を使い，ほぼ We の值 110 を境として，We に依存寸る領域と依存しない領域に区分されることを示した ${ }^{(13)}$. しかし, We $>110$ の領域における測定データが十 分でないため, 詳細な傾向については明らかでない部分があった. ミニギャップ沸騰系における薄液膜さに関す る研究はまだ少なく, さらにより詳細かつ広範な実験測定の必要があるとともに，狭险間隙の沸騰熱伝達率の正 確な予測のためには一般的に適用できる統一的な薄液膜厚さの予測方法の研究が必要であると考えられる. 本研 究では, これまでの水, トルエンおよびエタノールに，密度と表面張力が大きく異なる物性值を持つ HFE7200 の測定実験を加えた. さらに，平行平板間狭险間隙における薄液膜のより一般的な形成機構と特性についてスケ ーリング解析と次元解析により検討し，それらと測定結果と併せてより良好な薄液膜厚さに関する整理式を提案 する.

\section{2. 記 号}

A 消光係数 $\left[\mathrm{m}^{-1}\right]$ 
$a$ 気泡先端加速度 $a=V_{L}^{2} /(2 D) \quad\left[\mathrm{m} / \mathrm{s}^{2}\right]$

$D \quad$ 気泡生成点からの距離 $[\mathrm{mm}]$

$I$ 薄液膜等の存在している状態の検出器入射光強度

$I_{0}$ 間隙に蒸気だけの入っている状態の検出器入射光強度

$s \quad$ 間隙寸法 $[\mathrm{mm}]$

$V_{L} \quad$ 気泡先端局所速度 $[\mathrm{m} / \mathrm{s}]$

$\delta \quad$ 液膜厚さ $[\mu \mathrm{m}]$

$\delta_{0} \quad$ 初期薄液膜厚さ $[\mu \mathrm{m}]$

$\delta_{0 n} \quad$ 無次元初期薄液膜厚さ $\delta_{0 n}=\delta_{0} / \mathrm{s}$

$\delta_{V} \quad$ 速度境界層厚さ $[\mu \mathrm{m}] \quad \delta_{V}=\sqrt{\mu \mathrm{D} / \rho V_{L}}$

$\delta_{V n} \quad$ 無次元速度境界層厚さ $\delta_{V n}=\delta_{V} / \mathrm{s}$

$\rho \quad$ 密度 $\left[\mathrm{kg} / \mathrm{m}^{3}\right]$

$\mu \quad$ 粘性係数 $[\mathrm{Pa} \cdot \mathrm{s}]$

$\sigma$ 表面張力係数 $[\mathrm{N} / \mathrm{m}]$

無次元数

$\mathrm{Ca}$ Capillary 数 $=\frac{\mu_{L} V_{L}}{\sigma}$

We Weber 数 $=\frac{\rho s V_{L}^{2}}{\sigma}$

Bo Bond 数 $=\frac{\rho s^{2} a}{\sigma}$

\section{3. 実験装置及び方法}

図 3(a)に本研究で用いた実験装置の概略を示す. 前報(13) とほぼ同様であるので主要な点を以下に記す．ミニギ ヤップの上流に設けられ, 大気開放された液槽と加熱槽により, 脱気された液体がミニギャップ部に供給される. ミニギャップ部の試料液面高さは一定に保たれ，ミニギャップ及び加熱槽からの生成蒸気は凝縮器を経て水槽に 戻される. 図3(b)にミニギャップ部の詳細を示した．装置の構造材には，主としてレーザーに対して透過性の高 い石英ガラスを用いた。ミニギャップ部は，ギャップ中心線に対称に配置された 2 枚の石英ガラス伝熱板により 挟まれている，レーザー透過測定系は，ヘリウムネオンレーザー(直径 $2.6 \mathrm{~mm} ，$ 波長 $3.39 \mu \mathrm{m}$ )，セレン化鉛製光導 電素子ディテクタを用い, レーザー光がチョッパを経た後, ハーフミラーにて二方向に分光される. 分光された レーザー光の一方は液膜厚さ測定系であり, 平凸レンズを経て直径 $0.6 \mathrm{~mm}$ に絞られ，ミニギャップ部を通過する. その後, 両凸レンズ, 光学フィルターを介してディテクタに入射する. 他方はレーザー出力変動を補正するため に設置されており，同様に平凸レンズにて絞られ、両凸レンズ，光学フィルターを介して同様のディテクタに入 射する.レーザー消光法によって液膜厚さの算出に必要なレーザー透過割合 $I / I_{0}$ を同時に計測し，レーザー発生 器の出力変動を補正することができる．ここで，Io とIはそれぞれミニギャップに蒸気だけが充満している状態 のディテクタで検出された入射光強度とミニギャップ内薄液膜等の存在する状態の值を表している. ミニギャッ プ内の気泡挙動を観測するため, 高速カメラを用いてレーザー出力信号に同期させて撮影を行った.

本研究におけるレーザー消光法においては，式(1)の Lambert の法則に基づいて液膜厚さが求められる.

$$
\delta=-\left(\frac{1}{A}\right) \ln \left(I / I_{0}\right)
$$


ここで， $\delta$ とAはそれぞれレーザー光通過部の液膜厚さおよび試料の消光係数を表わしている. 本研究に用いら れたミニギャップ部に発生した蒸気泡とミニギャップ部を形成する両側の石英ガラスに挟まれ形成される 2 箇所 の薄液膜厚さの合計であるため，得られた薄液膜厚さの $1 / 2$ を薄液膜厚さとした，水,トルエンおよびエタノール の消光係数は文献(13)によった. HFE7200 の消光係数は，図(4)に示すように，あらかじめ間隙の設定された 2 枚 の石英ガラスを用いて測定した．なお，SUS304 を加工した薄膜を 2 枚の石英ガラスの間に挿入することにより 間隙を設定した. 表 1 は 4 種類の試料の消光係数を示している. なお, 液膜厚さの測定精度に関しては, 文献(14) で様々な要因の及ぼす影響について行った検討が適用され，本研究で用いられる 4 種類の試料において，使われ る $I / I_{0}$ の值は図 5 に示し, 十分な精度の測定が可能である.

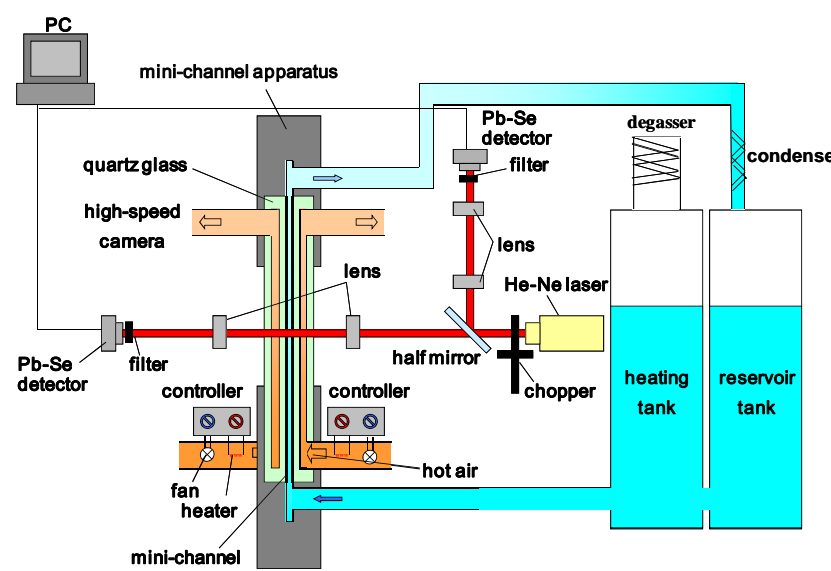

(a) Schematic of whole experimental system

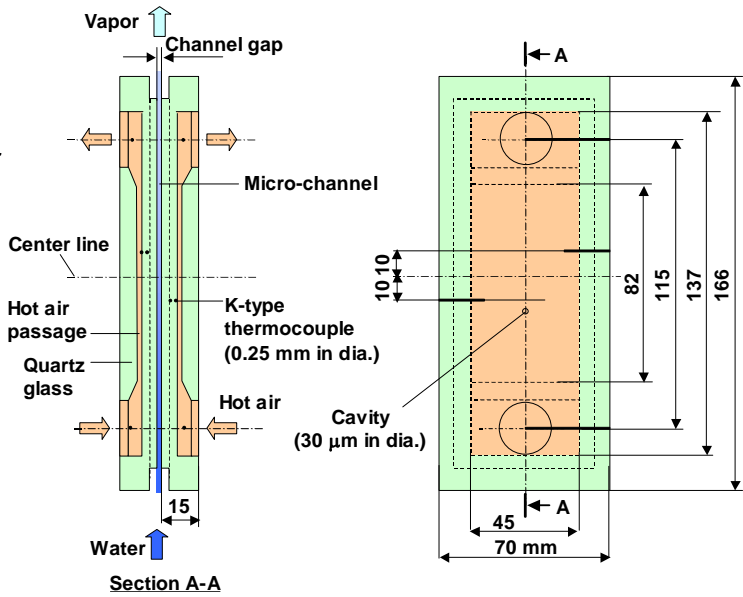

(b) Details of minichannel and heat transfer plate

Fig. 3 Experiment apparatus for measuring microlayer thickness

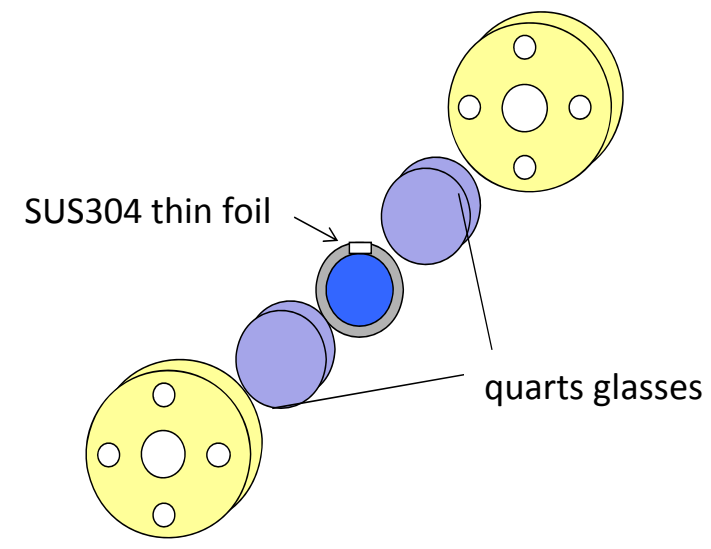

Fig. 4 Experiment apparatus for measuring extension coefficient

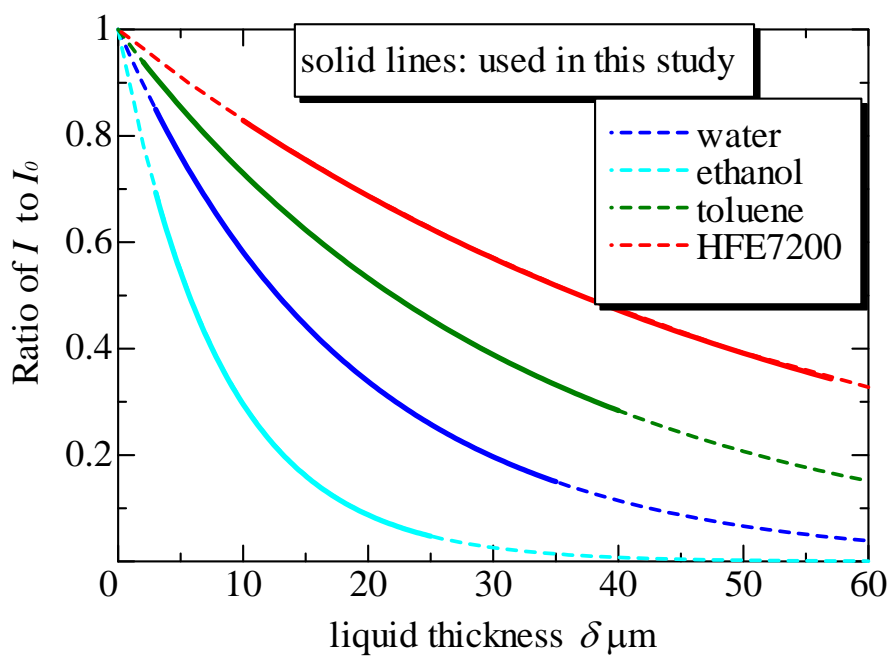

Fig. 5 Relationship between liquid thickness and ratio of $I / I_{0}$

Table 1 Extinction coefficient for water, toluene, ethanol and HFE7200

\begin{tabular}{ccccc}
\hline & Water & Toluene & HFE7200 & Ethanol \\
\hline$A\left(\mathrm{~m}^{-1}\right)$ & $5.42 \times 10^{4}$ & $3.15 \times 10^{4}$ & $1.88 \times 10^{4}$ & $1.09 \times 10^{5}$ \\
\hline
\end{tabular}




\section{4. 実験結果および考察}

図 6 は, 3 種類の間隙 $s=0.5,0.3,0.15 \mathrm{~mm}$ における純水，トルエンと HFE7200，および $s=0.15 \mathrm{~mm}$ におけるエ タノールを用いたときの気泡先端局所速度に対する初期薄夜膜厚さ変化を示している. 表 2 は 4 種類の試料の物 性值を示している。いずれの試料と寸法においても，初期薄液膜厚さは間隙寸法に顕著な影響を受け，間隙が狭 くなるにしたがって減少した．また，気泡先端速度が小さい領域においては，初期液膜厚さは気泡成長速度に強 い依存性を示し, 直線的に増加した。 さらに, 気泡先端速度が大きい領域においては気泡先端速度に対する依存 性が弱くなり, 平均的にはほぼ一定值あるいは微小ながら減少するが, 值の振れ幅は比較的大きい傾向を示した.

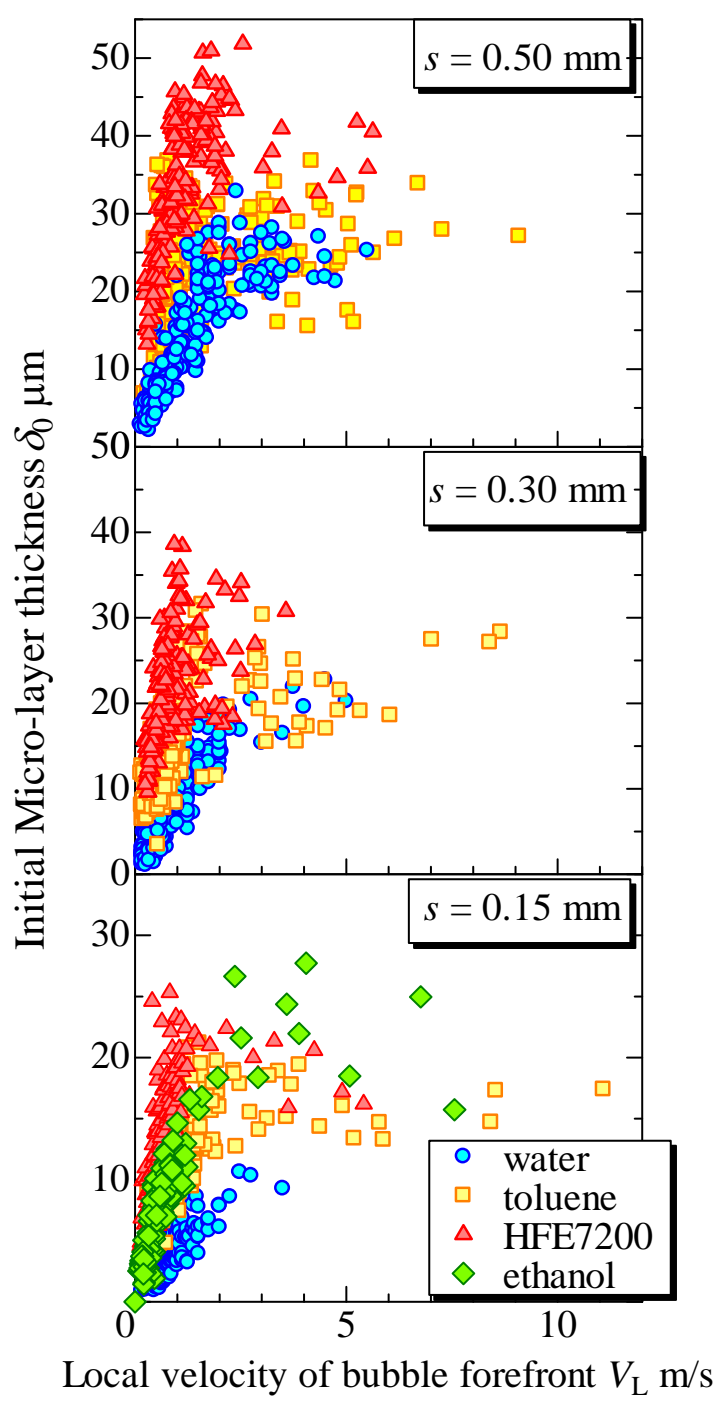

Fig. 6 Microlayer thicknesses versus local bubble forefront velocity for water, toluene, ethanol and HFE7200.

Table 2 Properties of the test fluids at 1 atm and saturation temperature.

\begin{tabular}{ccccc}
\hline & Water & Ethanol & Toluene & HFE7200 \\
\hline$\rho\left(\mathrm{kg} / \mathrm{m}^{3}\right)$ & 958.1 & 737.4 & 779.7 & 1307 \\
\hline$\nu\left(\mathrm{mm}^{2} / \mathrm{s}\right)$ & 0.295 & 0.612 & 0.318 & 0.250 \\
\hline$\sigma(\mathrm{mN} / \mathrm{m})$ & 58.9 & 18.5 & 18.1 & 9.4 \\
\hline
\end{tabular}




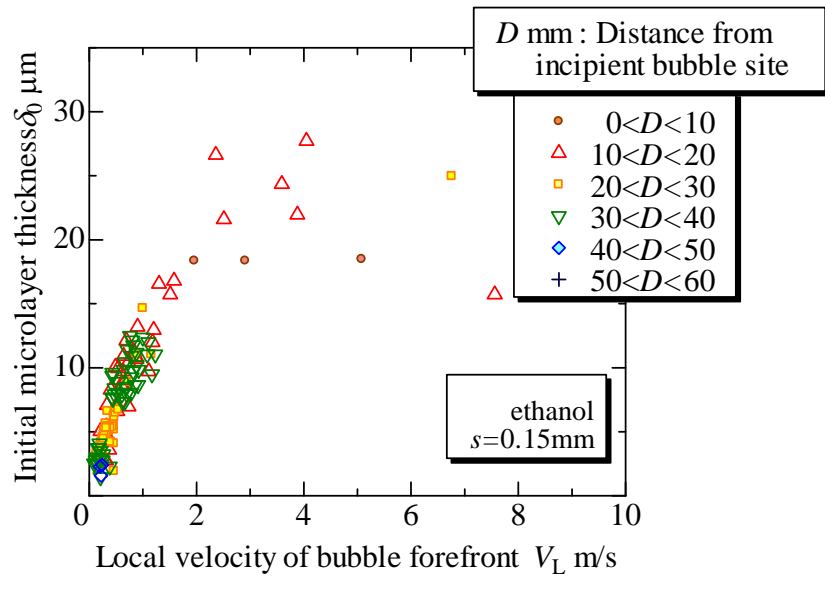

(a) Effect of $D$ for ethanol

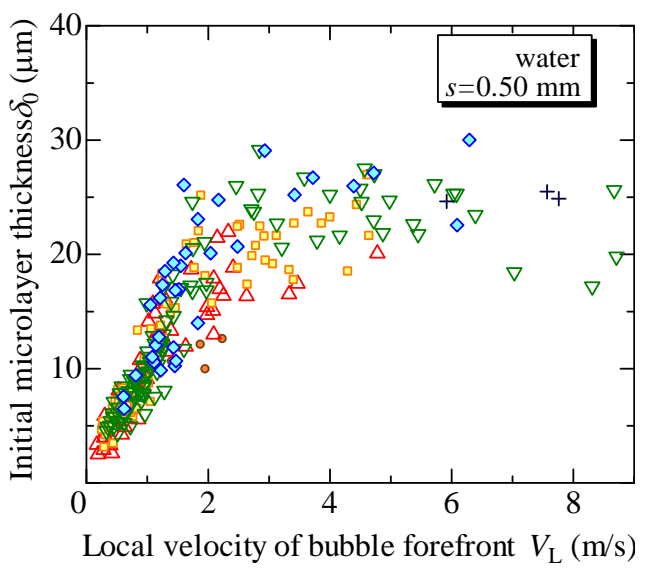

(b) Effect of $D$ for water

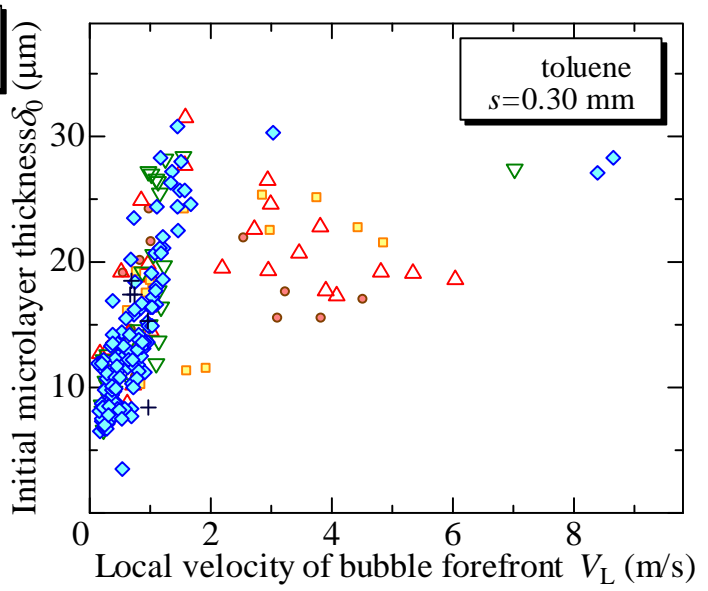

(c) Effect of $D$ for toluene

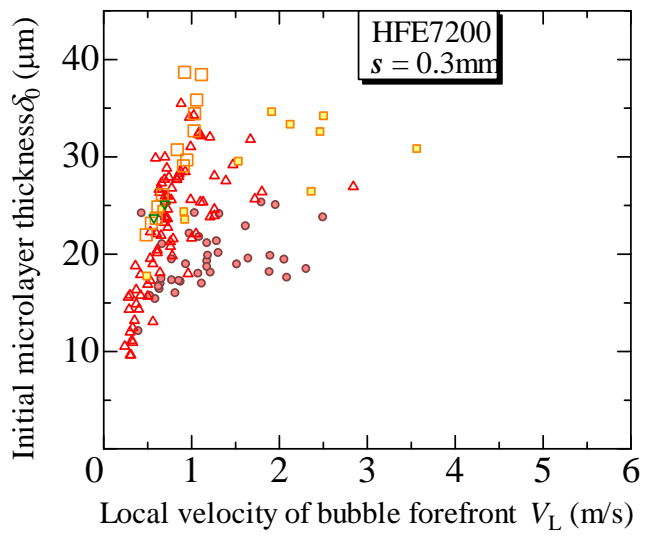

(d) Effect of $D$ for HFE7200

Fig. 7 Effect of distance from incipient bubble site

次に，図 7(a) (d)は，各試料における初期薄液膜厚さ $\delta_{0}$ に対する気泡生成点からの距離 $D$ の影響を示している. 気泡先端速度が小さい領域では, $D$ に対する依存性は弱いが, 気泡先端速度が大きい領域では, 同一の気泡先端速 度において Dが小さくなるにつれて薄液膜厚さが薄くなる傾向が得られた. このことから, 高速度領域では $D$ が 重要なパラメータであることが推察できる.

\section{5. 薄液膜形成機構と整理式}

はじめに薄液膜形成機構についてスケーリング解析と次元解析を用いて, 薄液膜構造を支配する無次元パラメ 一夕に関する考察を行う。なお，初期薄液膜形成は力学的関係に支配されると考えられるので，ここでは熱的な 影響は考えない. ギャップ内伝熱面と垂直方向の流れを無視すると, 気泡加速成長により, 気泡先端直前の液体 の流れは下記の非定常運動方程式で表わせる.

$$
\rho \frac{\partial U}{\partial t}+\rho U \frac{\partial U}{\partial x}=-\frac{\partial P}{\partial x}+\mu \frac{\partial^{2} U}{\partial y^{2}}
$$

ここで, 気泡の加速成長において加速度 $a$ を一定とし, 測定位置における気泡先端平均加速度および発泡点から 
の距離を用いると，式(2)左辺は式(3)のようになる.

$$
\rho \frac{\partial U}{\partial t}+\rho U \frac{\partial U}{\partial x} \sim \rho a+\rho \frac{V_{L}^{2}}{s / 2}
$$

図 8 に示したように, 発泡点から気泡先端領域を除いた平滑薄液膜領域では，薄液膜厚さの変化は，数ミリメー トルに対して液膜厚さは数マイクロメートルの範囲にあることから, 厚さの流れ方向勾配は無視できる. したが って，伝熱面とほぼ平行な薄液膜の気液界面の曲率はほとんどゼロと見なせる．気泡先端の曲率は急激にゼロか ら $2 / s$ に増加する.さらに, 蒸気泡内の圧力をほぼ均一とみな寸と, 表面張力による気泡先端部の薄液膜内の流 れ方向に式(4)の様な圧力勾配を生じると考えられる.

$$
-\frac{\partial P}{\partial x} \sim \frac{4 \sigma}{s^{2}}
$$

また，粘性項のオーダーは式(5)に示すように近似することができる.

$$
\mu \frac{\partial^{2} U}{\partial y^{2}} \sim \mu \frac{V_{L}}{\delta_{0}^{2}}
$$

以上のスケーリング解析により，式(2)は近似的に式(6)のように変形される.

$$
\frac{\delta^{2}}{s^{2}} \sim \frac{C a}{4-2 W e-B o}
$$

式(6)によると，ミニギャップ沸騰系のような加速流れの場合には, 薄液膜厚さは定常流れの場合とは異なり, $C a$ 数, We 数と Bo 数の関数として表されることを示している.

次に，次元解析による関係式を導き出すことを試みた．式(7)に示すように，薄液膜の形成は基本的に 7 個の物 理量により決定される.

$$
\delta_{0} \sim f\left(V_{L}, D, s, \rho, \mu, \sigma\right)
$$

$\pi$ 定理により, 上記のスケーリング解析と同様に, 無次元初期液膜厚さ $\delta_{0} / \mathrm{s}$ は $C a$ 数, We 数および Bo 数の関数 として無次元数の関係を導くことができる.ここでは, Moriyama-Inoue ${ }^{(10)}$ が採用したように, 高速度領域では薄

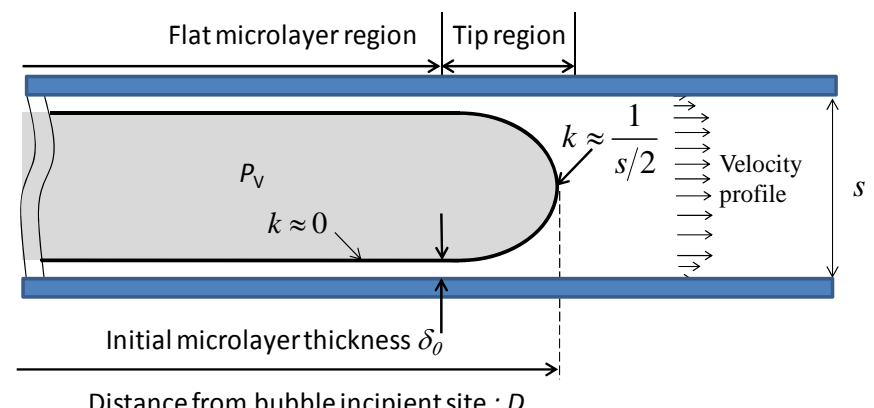

Fig. 8 Schematic diagram of bubble forefront in microchannel 
液膜の形成は境界層厚さ $\delta_{V}=\sqrt{\mu D / \rho V_{L}}$ に強く関係寸ると考えられるため, $\delta_{V}$ により $\delta_{0}$ を無次元化した. また， 前述の測定結果から， $\delta_{0}$ の物性值 $\rho, \mu, \sigma \sim の$ 依存性あるいは $V_{\mathrm{L}} ， s$ などに対する傾向等を参考にした. す なわち, 薄液膜厚さには $\delta_{0} \sim \rho \mu V_{L} s / \sigma$ の関係が導かれ, 式(7)の諸パラメータの次元を参考にして無次元数 $\rho \mu V_{L}{ }^{3} s / \sigma^{2}$ を誘導した. 次に, 無次元数 $\rho \mu V_{L}{ }^{3} s / \sigma^{2}$ を用いて, 薄液膜厚さを次のような形で表すことを試みる. な お, 式(8)の無次元表示は, 後述のように, $C a$ 数, We 数, Bo 数および $\delta_{0} / \mathrm{s}$ の関係式として表すことができる.

$$
\frac{\delta_{0}}{\delta_{V}}=f\left(\frac{\rho \mu V_{L}^{3} s}{\sigma^{2}}\right)
$$

図 9 に実験データの整理結果を表示した。ここではデータ数が多くそれぞれの試料の特性を確認しにくいため,

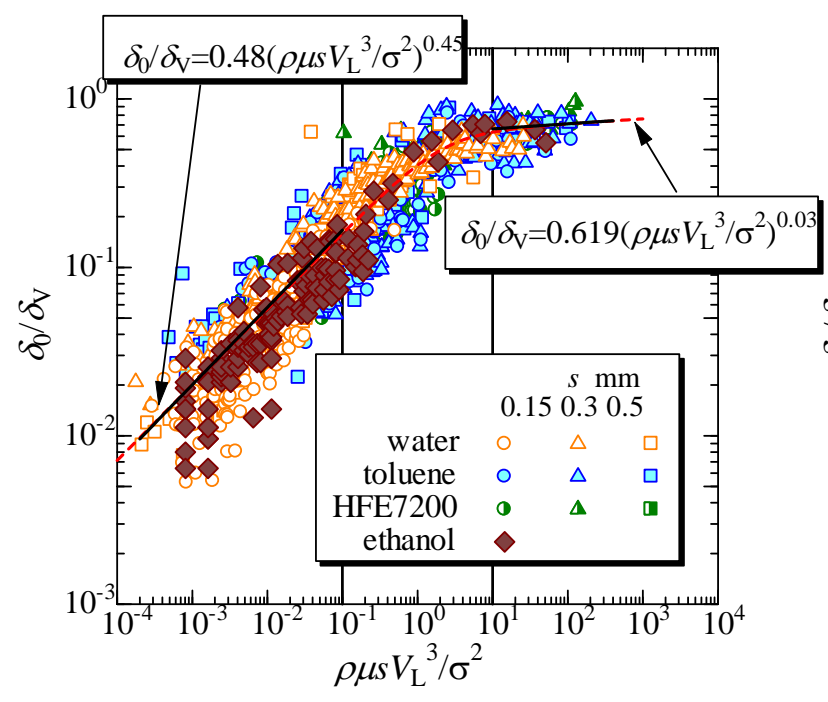

(a) Ethanol on the top

(c) Toluene on the top

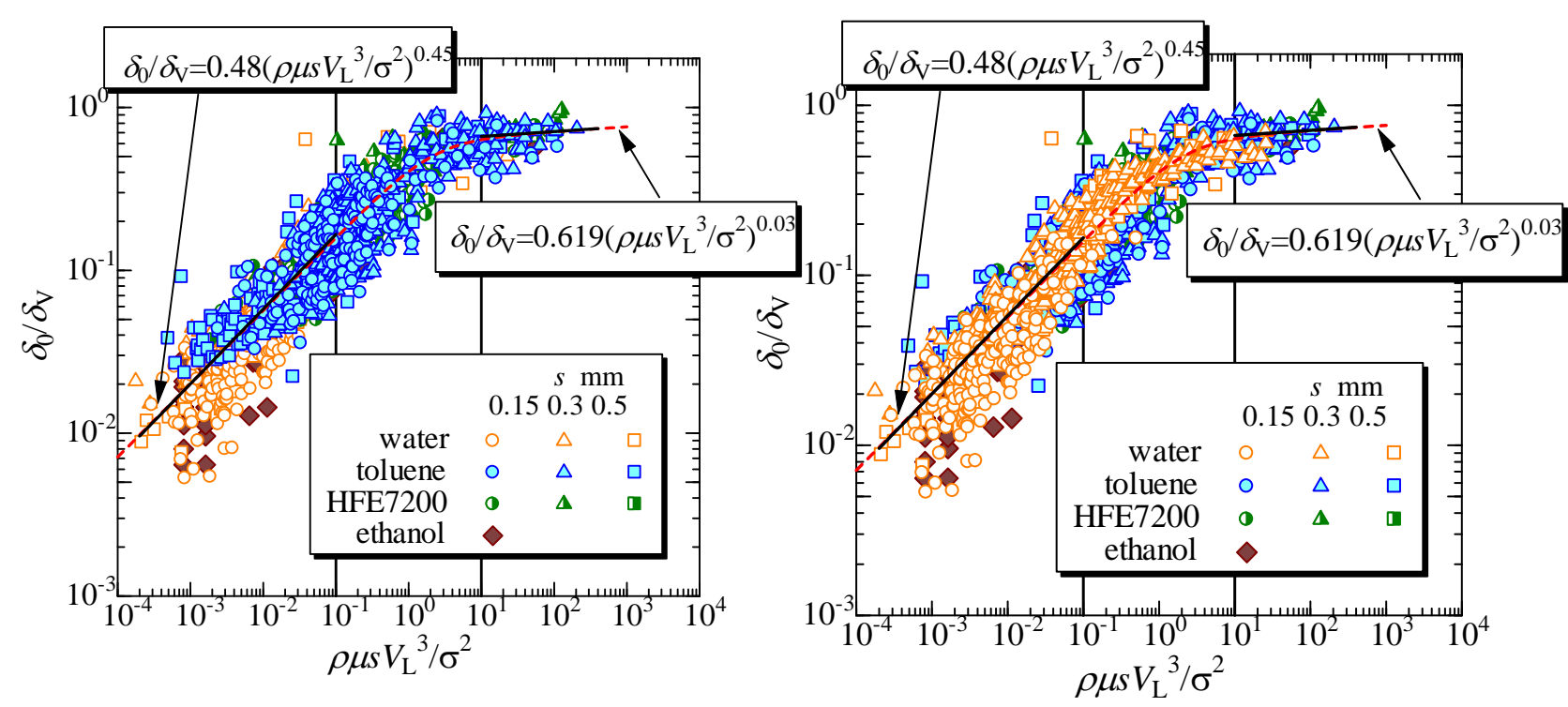

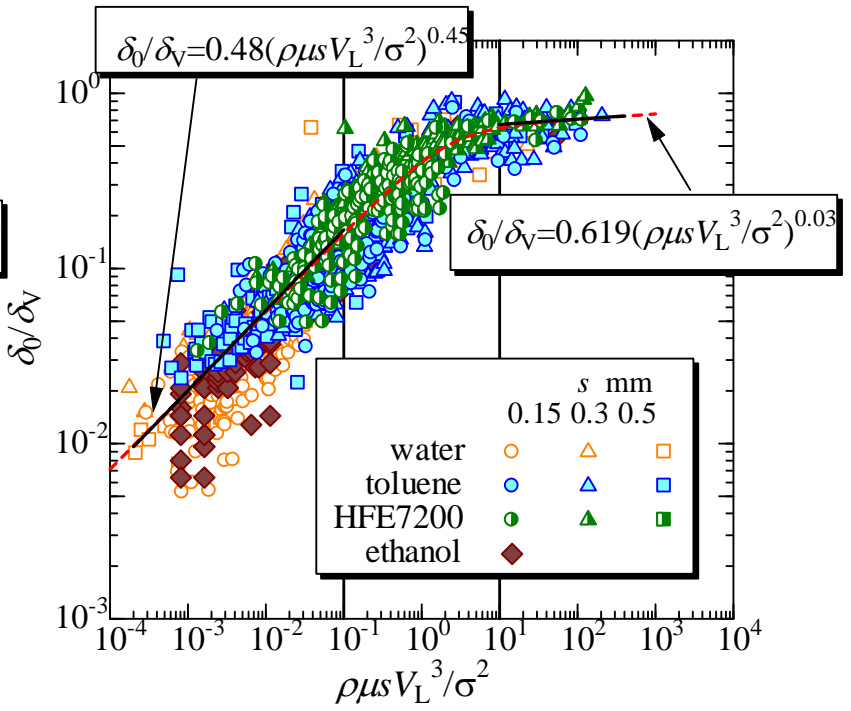

(b) HFE7200 on the top

(d) Water on the top

Fig. 9 Microlayer thickness nondimensionalized by viscous boundary layer versus dimensional group $\rho \mu V_{L}{ }^{3} s / \sigma^{2}$ 
各試料を前面に表示した場合を別々に示している. 式(9)と(10)はそれぞれ $\rho \mu V_{L}{ }^{3} s / \sigma^{2}<0.1$ と $\rho \mu V_{L}{ }^{3} s / \sigma^{2}>10$ 領 域のデータに対する整理式を示している. 試料種類と間隙寸法と関わらず, 実験データに対して $\rho \mu V_{L}^{3} s / \sigma^{2}$ と $\delta_{0} / \delta_{V}$ の対応関係が良好に表されることが分かる. 図 9 から得られた 2 つ式 (9)と(10)（図 9 に実線で表示) を組み合わせることにより全体を式(11)（図 9 に破線で表示）により表すことができる．式(9)と(10)に用いた直 線上に変化する領域の間の遷移領域と考えられる領域についても式(11)により，良好に表されることが確認され る.

$$
\begin{gathered}
\frac{\delta_{0}}{\delta_{V}}=0.48\left(\frac{\rho \mu V_{L}^{3} S}{\sigma^{2}}\right)^{0.45} \\
\frac{\delta_{0}}{\delta_{V}}=0.619\left(\frac{\rho \mu V_{L}^{3} s}{\sigma^{2}}\right)^{0.03} \\
\frac{\delta_{0}}{\delta_{V}}=\left\{\left[0.48\left(\frac{\rho \mu V_{L}^{3} s}{\sigma^{2}}\right)^{0.45}\right]^{-8}+\left[0.619\left(\frac{\rho \mu V_{L}^{3} s}{\sigma^{2}}\right)^{0.03}\right]^{-8}\right\}^{-1 / 8}
\end{gathered}
$$

なおここで, 式 (9)に対応する比較的速度の低い領域においては，薄液膜の形成が境界層に強く依存するわけ ではないと考えられる.しかし，前述のように沸騰現象においては, 加速的な蒸気泡の成長をともなっており, またある程度の速度を有する範囲を含んでいるため, 薄液膜厚さは粘性および表面張力に加えて, 慣性力および 加速度の影響を考慮することが望ましいと考えられる. 式(11)を変形すると, 無次元薄液膜厚さ $\delta_{0} / \mathrm{s}$ は $C a$ 数, Bo 数およびWe 数の関数として式(12)のように表されるため, 全データ領域について統一的に表示することが可 能であると考えられる．ここで加速度に関連して， $a=V_{L}^{2} /(2 D)$ の関係から，式(11)には $\delta_{V}$ 中に $D$ の形で含まれ るが，式(12)ではBo 数に $a$ の形として表されている.

$$
\frac{\delta_{0}}{S}=\left\{\left[0.34 C a^{0.95} W e^{0.45} B o^{-0.5}\right]^{-8}+\left[0.43 C a^{0.53} W^{0.03} \mathrm{Bo}^{-0.5}\right]^{-8}\right\}^{-1 / 8}
$$

次に, 式(12)と実験データの対応について詳細に比較する. 図 10(a) (j)に実験データを一定範囲の We 数ごと に，実験データと式(12)の比較を表示した．ここで，同時に表示されている Bo 数範囲は，We 数範囲に対応して いる. 実線と破線は式(12)により，対応する範囲のWe とBo の境界值を示している.いずれのデータ範囲に対し ても，無次元薄液膜厚さはほぼ式(12)でまとめられることが確認される.

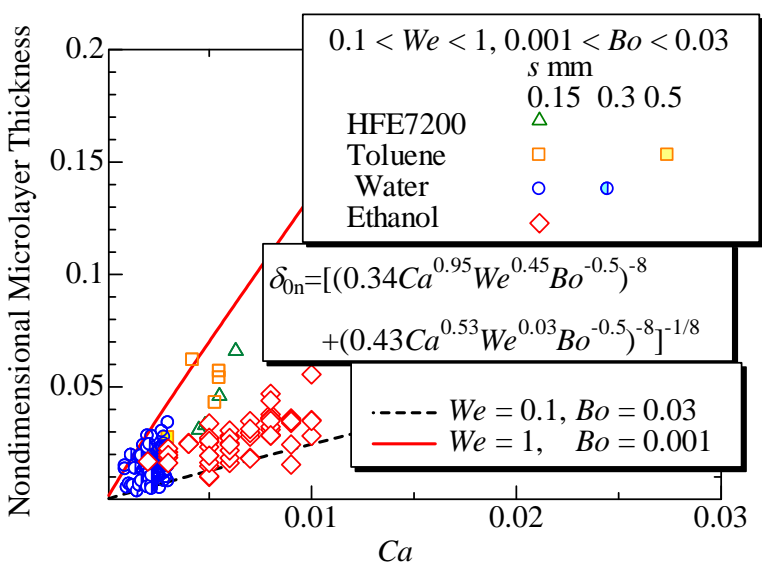

(a)

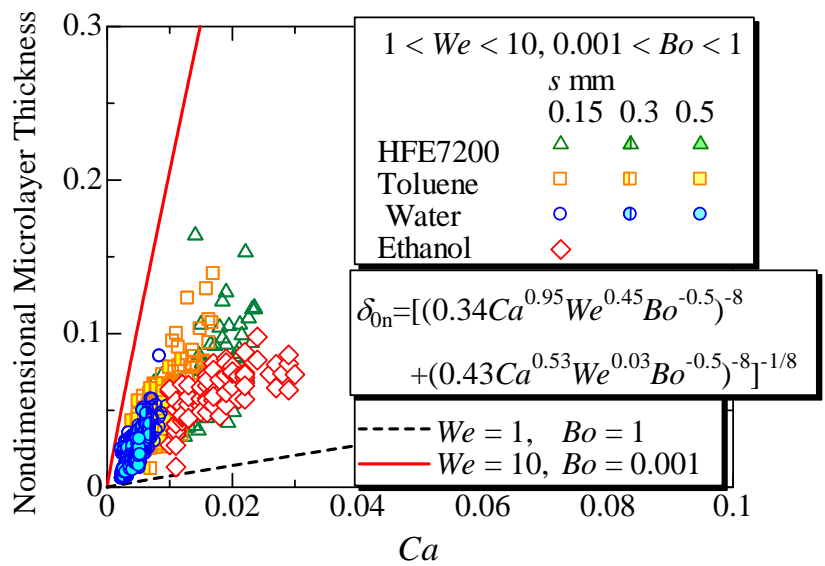

(b) 


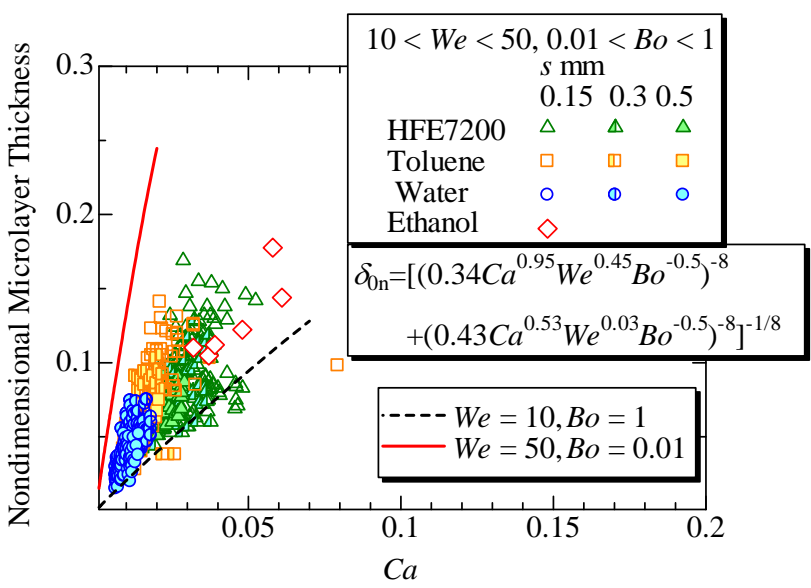

(c)

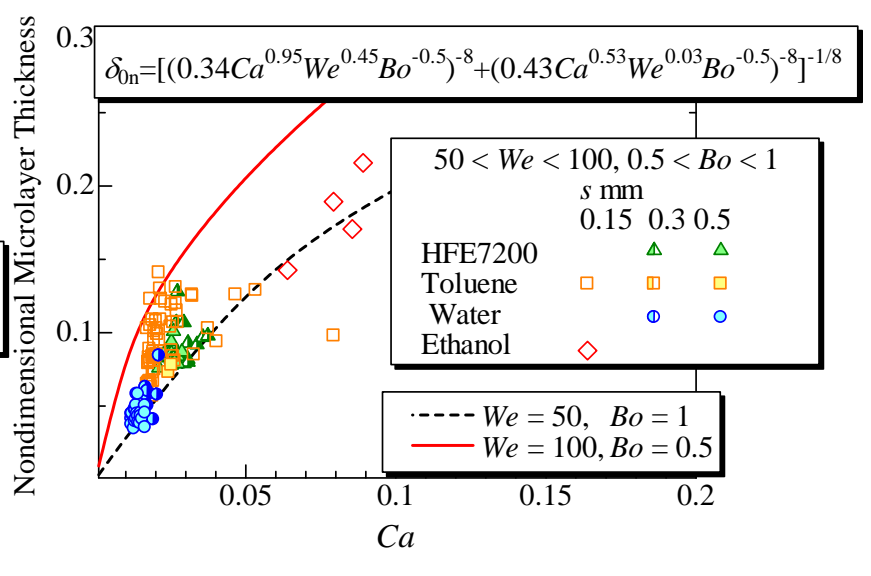

(d)

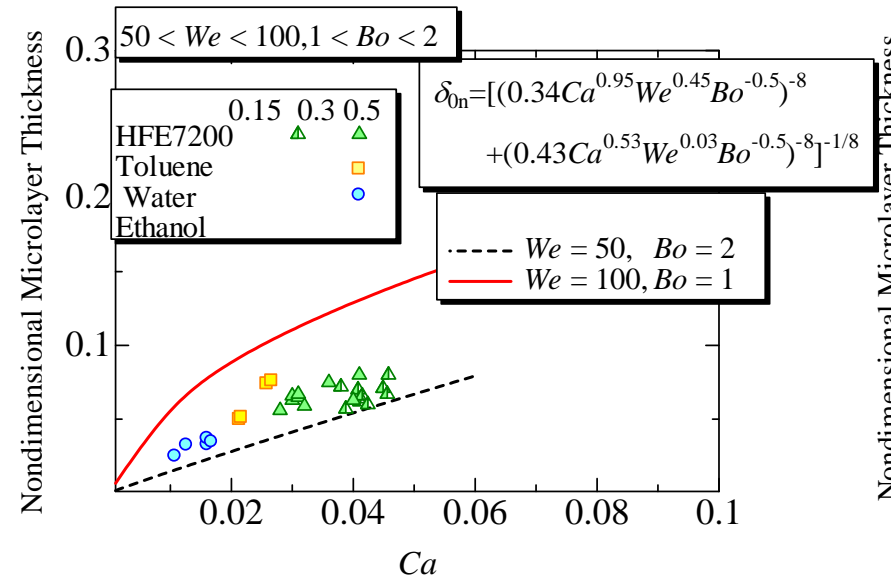

(e)

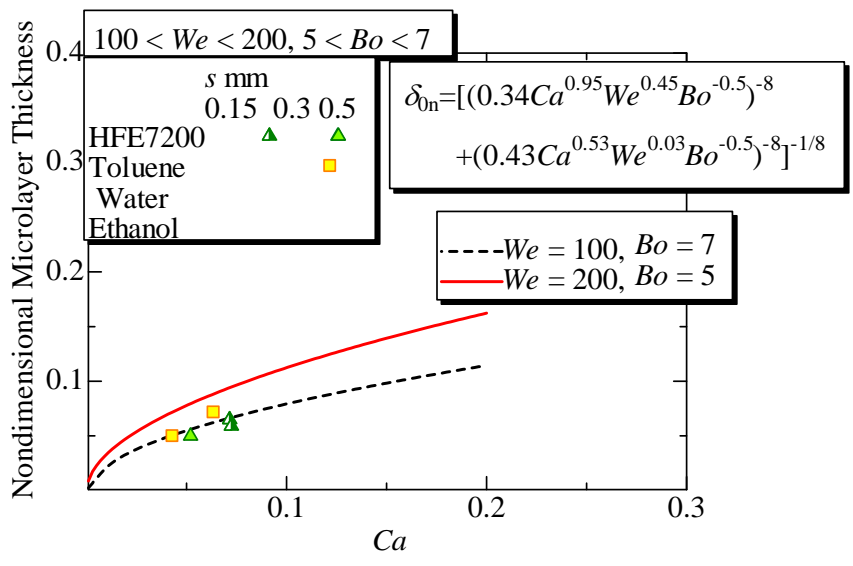

(g)

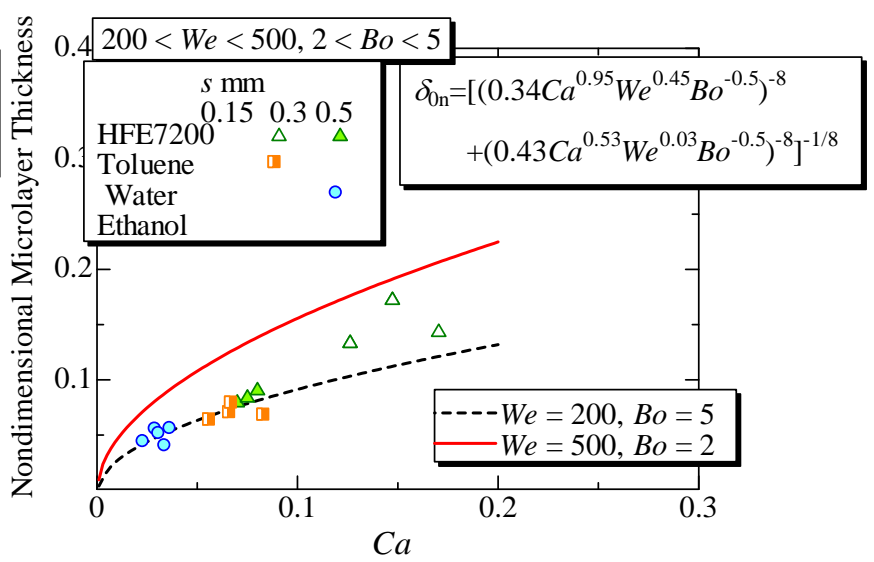

(h) 


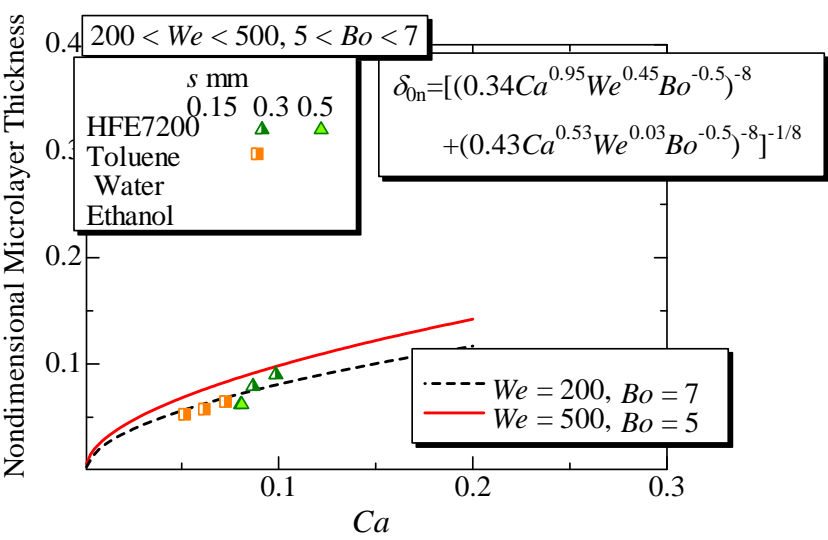

(i)

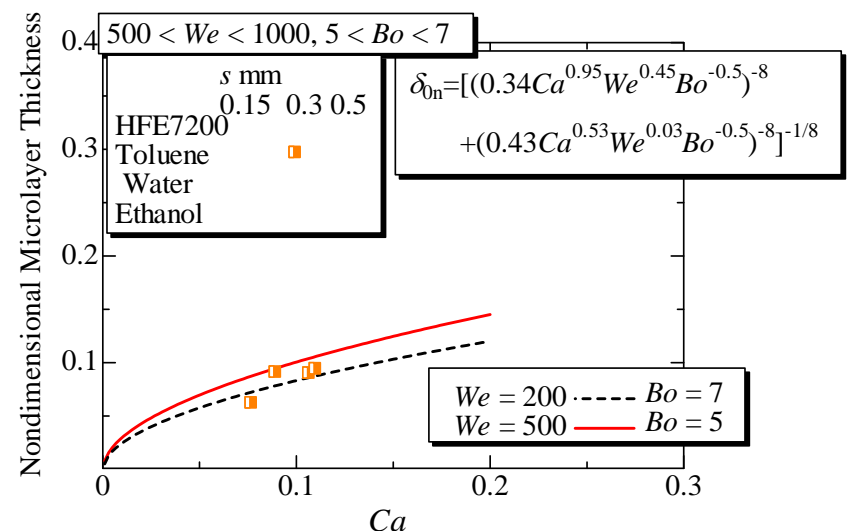

(j)

Fig. 10 Comparison between correlations and experiments

\section{6. 結 論}

ミニギャップ内沸騰現象における薄液膜形成機構と沸騰特性を明らかにするために，純水，トルエン，エタノ ールと HFE7200 を用いて, 蒸気泡と伝熱面間に形成される薄液膜厚さの測定結果を基に，スケーリング解析と次 元解析により支配無次元数を検討した。その結果は以下のように表すことができる.

（1）広範な流体物性をカバーする水，エタノール，トルエンおよび冷媒 HFE7200 を試験流体として用い，0.15mm, $0.3 \mathrm{~mm}$ および $0.5 \mathrm{~mm}$ の 3 通りの間隙寸法における測定実験を行った. 各試験流体において，初期液膜厚さは 主に間隙寸法および気泡先端速度により決定され，また気泡発生点からの距離の影響が気泡速度の増大とと もに重要になることを明らかにした。

(2) ミニギャップ内沸騰系における薄液膜形成は, 薄液膜の蒸発により加速成長となることに対応して，非定常 運動方程式のスケーリング解析と次元解析を用いて系を支配する無次元数の関係を示した. すなわち，初期 液膜厚さ $\delta_{0}$ を間隙寸法 $s$ による無次元薄液膜厚さ $\delta_{0} / \mathrm{s}$ が $C a$ 数, We 数と Bo 数の関数として，また $\delta_{0}$ を速度 境界層厚さ $\delta_{V}$ により無次元化した無次元初期薄液膜厚さ $\delta_{0} / \delta_{V}$ が無次元数 $\rho \mu V_{L}^{3} s / \sigma^{2}$ にり整理されるこ とを示した。

(3) 上記(1)における初期薄液膜厚さの測定結果を， $\delta_{0} / \delta_{V}$ と $\rho \mu V_{L}^{3} s / \sigma^{2}$ の関係式として一通りに表示される整 理式を提案した. また， $\delta_{0} / \mathrm{s}, \mathrm{Ca}$ 数, We 数とBo 数の関数としてその関係式を表した.

\section{文献}

(1) Tasaki, Y. and Utaka, Y., "Effect of Wettability on Boiling Heat Transfer Characteristics in Micro-Channel Vapor Generator", International Journal of Transport Phenomena, Vol.5, No.4 (2003), pp.295-302

(2) Utaka, Y., Okuda, S. and Tasaki, Y., "Configuration of the micro-layer and characteristics of heat transfer in a narrow gap mini/micro-channel boiling system”, International Journal of Heat and Mass Transfer, Vol.52, (2009), pp.2205-2214.

(3) Thome, J.R., Dupont, V. and Jacobi, A.M., "Heat Transfer model for evaporation in microchannels. Part I: presentation of the model”, International Journal of Heat and Mass Transfer, Vol.47, (2004), pp. 3375-3385

(4) Taylor, G.I., "Deposition of a viscous fluid on the wall of a tube”, Journal of Fluid Mechanics, Vol.10, Issue 2, (1961), pp. 161-165.

(5) Bretherton F.P., “The motion of long bubbles in tubes”. Journal of Fluid Mechanics, Vol.10, Issue 2, (1961), pp.166-188. 
(6) Katto, Y., and Shoji, M., "Principal mechanism of micro-liquid-layer formation on a solid surface with a growing bubble in nucleate boiling”, International Journal of Heat and Mass Transfer, Vol.13 (1970), pp. 1299-1311

(7) Aussillous, P. and Quere, D., “Quick deposition of a fluid on the wall of a tube”, Physics of Fluids, Vol.14 (2000), pp. 2367-2371.

(8) Zhang, Y.H. and Utaka, Y., “Characteristics of microlayer formation and heat transfer in mini/microchannle boiling systems: A review”, Frontiers in Heat and Mass Transfer, Vol.3, No.1 (2012), 013003.

(9) Han, Y. and Shikazono, N., "Measurement of the liquid film thickness in micro tube slug flow", International Journal of Heat and Fluid Flow, Vol.30, No.5 (2009), pp.842-853

(10) Moriyama, K., and Inoue, A., "Thickness of the liquid film formed by a growing bubble in a narrow gap between two horizontal plates”, Transactions of the ASME, Journal of Heat Transfer, Vol.118 (1996), pp.132-139.

(11) Han, Y. and Shikazono, N., "The effect of bubble acceleration on the liquid film thickness in micro tubes", International Journal of Heat and Fluid Flow, Vol.31 (2010), pp. 630-639.

(12) 宇高 義郎, 田崎 豊, 奥田 修平, ”レーザー消光法によるミクロチャネル沸騰系における薄液膜挙動の観測”, 日本機械学会論文集 B 編, Vol. 71, No. 704 (2005), pp. 1133-1139.

(13) Zhang, Y.H., Utaka, Y. and Kashiwabara, Y., "Formation Mechanism and Characteristics of a Liquid Microlayer in Microchannel Boiling System”, Transactions of the ASME, Journal of Heat Transfer, Vol.132, No.12 (2010), 122403-1--122403-7.

(14) 宇高 義郎, 西川 哲治, ”レーザー消光法による濃度差マランゴニ凝縮過程における凝縮液膜厚さの非定常測定 （測定結果とその検討）”，日本機械学会論文集 B 編， Vol. 68, No. 672 (2002), pp. 2292-2299. 